Journal of Social Sciences 7 (3): 447-450, 2011

ISSN 1549-3652

(C) 2011 Science Publications

\title{
Unique Identity of Lanna Silver Jewelry: A Development as a Commercial Product
}

\author{
Panashat Inkhong \\ The Research Institute of North Eastern Arts and Culture, \\ Maha Sarakham University, Maha Sarakham, 44000
}

\begin{abstract}
Problem statement: Silver metal could be used as precious art and economic ornaments or jewelries. The objectives of this research were to study the comparison in production sources of Lanna Silver Ornaments, the molded lime pattern from Lanna Identity Architecture using in designing the silver product accessories, the design of silver accessories from molded lime of Lanna Identity Architecture and the development of product in Commercial Lanna Identity Silver Accessories. Approach: The research area was the North Region including: Chiengmai, Lampoon, Payao, Chiengrai, Lampang, Pra and Nan Provinces. The samples as informants were selected by Purposive Sampling, for 59 persons. The instruments using for collecting data included: The interview form, the observation form, focus group discussion and participatory workshop. The obtained data were classified into groups for designing and analyzed according to specified objectives. The research findings were presented in descriptive analysis. Results: The production origin of Lanna Silver Ornaments included in all of 8 provinces. Most of them were produced as community business. For obvious industrial production system, it was in Chiengmai Province and Nan Province. Most of designs and patterns were similar. The production technique was the traditional and modern technology, the study of molded lime from Lanna Identity Architecture in Mungrai Dynasty, the age of King Ti-lokarach, the most beautiful art work, the design of silver ornaments from molded lime pattern of Lanna Identity Architecture, selected from pattern showing identity of molded lime design linking the pattern as the flora implying auspicious sign and the development of product in Lanna Identity Silver Ornaments starting from the product design and development, combined material, market planning, analysis of consumer group and application of new technology in production. Conclusions/recommendations: This research could be a guideline in designing the product. The silver ornaments with art value and way to plan for jewelry market in tour places, could be able to create the income for locality leading to sustainable economic system in future.
\end{abstract}

Key words: Unique identity, silver jewelry, commercial product, silver metal

\section{INTRODUCTION}

According to the study and survey of overall situation of manufacture art work in North Region Silver Ornaments, Area 8, North Region Province, various major problems were found: the pattern lacked of identity of being Lanna Ornaments since the design was according to the specialist producer. The same pattern was carried on. So, there were no new creative patterns. As a result, it affected the consumer's taste of consumer who didn't see the originality of those ornaments. The productions were in former patterns as well as the discontinuity of marketing. The price went up. So, the ornaments price went up as well. It affected the decrease of selling. Therefore, the role of design occurred from approach in using the other kinds of material as element for creating the new pattern as an integration of material for increasing value from perception. The consumer could perceive it. In addition, it might affect the marketing in long range. If considering the situation of Thai Cult6ure and Society, found that Thai People's Value still focused on material with the price so that it could be sold or show their status from the price of material.

Furthermore, there was no relationship between the amount of selling and production. The amount of buying each time was less than the amount of production. The producers imitated the customer's ornament brought for producing. The development in design was less than the competitor nations. The shops producing and selling were in succession for closing their enterprise. Consequently, there was an impact in inheriting the cultural work as manufacture art in silver ornaments as well as creation of identity of locality for serving the policy of government needed to create the economic in locality. So, the application of wisdom in locality such as general architectural ornament. In North Region, included the pattern with prominent identity 


\section{J. Social Sci., 7 (3): 447-450, 2011}

could be able to create various inspirations in ornaments whereas the decorated patterns of Lanna Architect often showed an identity of Thai Lanna to be well known for general public as well as caused the usefulness and economic opportunity for people in locality.

According to the major problems and issues, the researcher had approach in conducting research titled "Development of Product of Lanna Identity Silver Ornaments for Creating Supplementary Commercial Value," for developing the new styles with value and identity of Lanna Ornaments from inspiration in pattern of molded lime design and community need in order to create the beautiful concurrent pattern from valuable material as well as express Lanna People's identity of traditional wisdom of Lanna People and maintenance of belief in using combined materials for developing the modern pattern and new beautiful pattern congruent with consumer's taste in those periods. There was an inheritance of Lanna Wisdom through the design work of precious jewelries both of more valuable pattern and design. aConsequently, there was more community developments and increased extension to national economic level.

\section{MATERIALS AND METHODS}

The studied area included Chiengmai, Lampoon, Pa-yao, Chiengrai, Lampang, Prae and Nan Provinces. Qualitative Research Methodology was administered in this research by collecting data from the samples by Purposive Sampling including 3 experts, 8 practitioners and 48 related persons. Data were collected from documents and field study by using the Survey, Observation, Interview, Focus Group Discussion and Workshop for leading to designing and market planning. Data groups were investigated and analyzed based on objectives. The research findings were presented in descriptive analysis.

\section{RESULTS}

The research findings were as follows:

- The source of production I Lanna Silver Ornaments, produced in all of 8 Provinces. Most of them produced as community business. There were productions in obvious industrial system in Chiengmai Province and Nan Province. Most of the designs and patterns were similar since the specialist producers were hill tribe people. So, the productions were like the former patterns as usual. For the production technique, it included both of ancient style and mould style
- The study of molded lime from Lanna Identity Architecture in Mungrai Dynasty in the period of King Ti-loksrach including prominent art design, brought for conveying the Lanna Identity clearly and beautifully. The pattern with identity pattern was the moved around stalk and curved head often found in the reign of King Ti-lokarach. So, it was easily remembered. When it was applied in designing $g$ the ornaments, it was conveyed the identity very well

- The design of silver ornaments from molded lime of Lanna Identity Architecture, the pattern with local identity which could show the value with prominent attribute, should be selected especially the pattern of flora implying the meaning of auspicious sign would be able to be the most interesting point from the consumer

- The development of product in silver ornaments of Commercial Lanna Identity should start from the development in creating the advantage of the product itself by designing and developing the ornament product combining different materials on the basis of Lanna Identity Pattern in order to develop the advantage in marketing by surveying the need of consumer group as well as technology in production and management by analyzing the situation of product in order to know about the product should be produced to be congruent to the consumer group in each group. In the meanwhile, the marketing should be planned for knowing the target group, product position, price position, value to given to the consumer, selling strategy and communication strategy which the marketing constituent should be developed for the most efficient level

\section{DISCUSSION}

According to the findings, could be discussed as follows:

Comparison of origin in producing Lanna Silver Ornaments: The research findings found that Lanna Silver Ornaments had major sources of production in Chiengmai and Nan Provinces. The production origin in Chiengmai Province produced many silver ornaments especially in Sankampang District and Wua-lai Street. In Sankampang District, most of them produced in large sized industrial Factories producing a large amount of number including the industrial group of Sankampaeng Silver Ornament, Ar-jongti-o-ro Company Limited. 

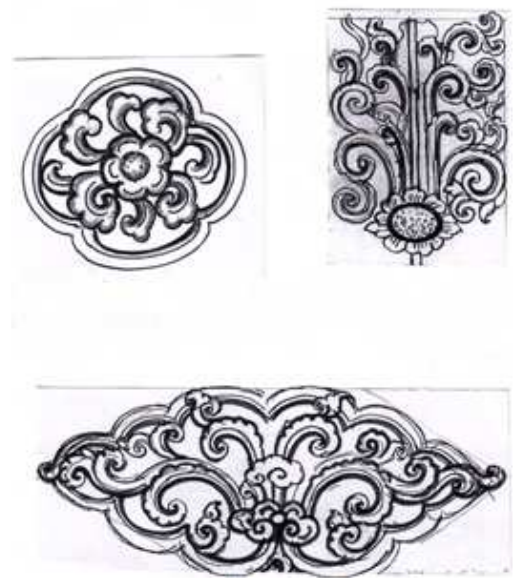

(a)

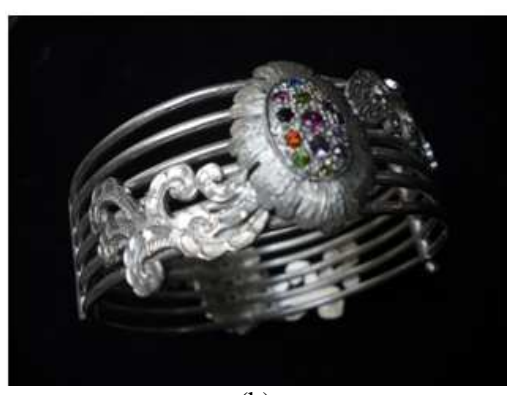

(b)

Fig. 1: Silverware as appliance and ornament group

There were various patterns including both of mould pattern and ancient pattern which was knowledge of locality practicing from generation to generation (Fig. 1). It was a business which villagers integrating their knowledge in locality as well as learning from the other locals with continuous development. It was supported) statement that there were 2 forms of selling system as: the market in the country including 3 types of selling: retail as the direct selling to consumers since Chiengmai was a large province and major tour source of Thailand, the producers both of large enterprise and large enterprise produced and sold by themselves to the people who prefer the silver items. Besides, the producers could be able to sell as retail by bringing the products for sell in booth of annual ceremony in different places, the road for people to walk, including many tourists both of Thai People and foreigners were consumers. Consequently, his kind of manufacture could be sold in a large amount of number.

For pattern of molded lime from Lanna Identity Architecture: The research findings found that the pattern or design of molded lime from Lanna Architecture in Mungrai Dynasty in Chiengmai City, could be classified pattern based on style of pattern, into 4 groups including: Pattern Group 1: Lanna Bunch Pattern, Group 2: Flora Pattern of stalk moving around and the curved top including the cloud and flower pattern, Group 3: artificial flower pattern with stalk linking flower and leaf and Group 4: the inside pattern of board was the flower on rhombus frame with the overlapped petals both of one layer and two layers. Then, they were selected for 3 patterns left and designed the ornaments with Lanna Identity from the pattern. In addition, the approach of inspiration from Lanna Appliances as components aligned with basic pattern of Geometry which was popular, was applied in designing with concurrent style very well and easily accessed to consumers. It was supported by Design Theory of Design. The research findings found that in designing the silver ornaments from pattern of molded lime in Lanna Identity Architecture both of general consumers and consumers in the area and natural environment. It was supported by Ponrungroje (2000) findings in "Pattern of Precious Stone for Developing the Export Industrial," with conclusion that each ethnic group preferred different patterns of ornaments. For instance, the geometric pattern was popular in the U.S., whereas free designed shape was the pattern preferred in other countries The bright color precious stone was popular in forming setting. Therefore, all of 3 sets silver ornaments were designed by applying theories and testing the consumers. It was believed in appropriateness with Concurrent Lanna Identity. It was supported by Bao et al. (2004) approach that the Lanna Art in architecture work owing to Buddhist Religious, could be able to design or apply with the set or ornaments. So, it was the creation of supplementary value for the work piece.

In the development of silver ornament products in commercial Lanna Identity, the research findings found that the development of silver product in Lanna Identity Silver Ornaments regarding to beauty of pattern, material relation, constituent relation, meaning convey, the form of wanted silver ornaments, could be concluded in 2 ways: the process in producing the product and the increase of commercial product value. The process of product development was performed according to 2 major consumer groups: the teenager group and working age group. Both groups had different preferences: the adolescent group preferred simple and new style while the working group liked delicate pattern, the concurrent pattern of that local identity should be combined. For the selection for buying ornaments, the consumers would select it from the shops in tour places from different provinces by 
considering information from television media and distributed brochure mostly. For process increasing commercial product, the issues of management and marketing were considered staring from the situation analysis of product from related external factors affecting the product. It was supported by Agarwal (1983) approach that the creation of commercial advantage should be determined by marketing strategic plan. Therefore, according to analysis of situation for product at 4 places of the origin in producing from external factor, found that the consumers bought silver ornaments most. They often bought small piece of silver jewelries such as ring, bracelet, necklace and earring respectively. When analyzing the situation of product, the consumer as common target was analyzed in order to know information in buying silver decorations and brought it for determining the strategy as prominent attribute of the products, special technology, development of items quality, items delivery, in order to serve the need most. It found that the target consumers buying silver jewelries, were particular groups needed to be clearly specified. Meanwhile, there was another prospect group who might be buyers in the future as well. So, the major positions were determined in Lanna Silver Ornaments from the state of being product from wisdom descending from ancestors with special skill and expertise including special producing technique. Furthermore, the way for selling most, should also be increased in order to approach future group consumer.

\section{CONCLUSION}

According to the above research studies, the specialists producing silver ornaments should be encouraged so that they would carry on the body of knowledge without changing to the other occupations.
Moreover, the way for more selling should be searched for in order to expand the market. The designers of ornament products should be recognized so that there would be new styles of jewelries to the market. The image of production origin should be created by developing the interesting atmosphere and relating to the items so that the consumers would have common feeling while they were entering to the ornament selling shops. The activities should be organized as well, for example, new year ceremony, valentine day, or mother's day for creating the consumers' shared feeling so that they had would want to buy since the season including the training for specialists in order to be able to make pattern as the order for producing correctly. In addition, new production techniques should be developed by sending the specialists for training in different efficient working units which might consult with the Department of Industrial Promotion.

\section{ACKNOWLEDGEMENT}

The research has been supported generously by the Mahasarakham University Research Fund. The researchers would like to express their sincere appreciation for all of the support provided.

\section{REFERENCES}

Agarwal, R.D., 1983. Organization and Management. 1st Edn., Tata McGraw-Hill Education, New Delhi, ISBN: 0074515063 , pp: 708.

Bao, Y., Q. Tian and L. Lane, 2004. Buddhist Art and Architecture of China. 1st Edn., Edwin Mellen Press, Lewiston, ISBN: 077346316X, pp: 199.

Ponrungroje, C., 2000. Research in Arts. 1st Edn., Samnakphim hǣng Čhulālongkọ̄nmahāwitthayālai Krung The $\square$ p, ISBN: 9743460454, pp: 175. 